\title{
Housing Assets and Household Risk Financial Assets
}

\author{
Su Xin ${ }^{1 *}$
}

${ }^{1}$ School of Finance, Guangdong University of Foreign Studies, Guangzhou 510000, China

DOI: $10.36347 /$ sjebm.2021.v08i05.001

| Received: 06.04.2021 | Accepted: 15.05.2021 | Published: 18.05.2021

*Corresponding author: Su Xin

Abstract

Housing value and family risk financial asset investment have received more and more attention from academia in recent years. This article uses the empirical findings of the China Household Finance Survey (CHFS) in 2015 to find that housing assets will not only significantly increase household participation in risky financial assets, but also increase household investment in risky financial assets. Furthermore, using the value-added of housing wealth as an instrumental variable to conduct research, it is found that the effect of housing wealth still exists significantly. The above research has important theoretical and practical significance for optimizing the allocation of household assets, improving the quality of people's lives, and improving the level of capital market in the context of rising housing prices.

Keywords: housing assets, risky financial assets, wealth effect.

Copyright $($ C) 2021 The Author(s): This is an open-access article distributed under the terms of the Creative Commons Attribution 4.0 International License (CC BY-NC 4.0) which permits unrestricted use, distribution, and reproduction in any medium for non-commercial use provided the original author and source are credited.

\section{INTRODUCTION}

In the ten years from 2008 to 2018 , China's stock financing increased from 385.2 billion yuan to 11378 billion yuan [1], and the total stock market value increased from 12.14 trillion yuan to 43.49 trillion yuan. The stock market funding and total stock market value have continued to rise rapidly over the past decade, and China's capital market represented by the stock market has achieved rapid development. However, from the perspective of financing structure, as of December 2018, China's direct financing accounted for only $30.7 \%$. During the same period, direct financing in the US social financing accounted for $77.7 \%$. Direct financing in Japan and Germany, with banks as the leading financial system, the proportion of financing also reached $52.2 \%$ and $39.6 \%$, respectively. Compared with developed countries, the proportion of China's direct financing is still at a relatively low level. Resident households are one of the three main players in the capital market, and their insufficient demand for risky financial assets is an important reason for the low proportion of direct financing (Yang Chengxun, 2004).

At the same time, the continuous rise of housing prices in the past ten years has attracted the attention of a large number of scholars. Since 1998, China has fully implemented the housing system reform, the government has loosened control over

1 The data comes from the National Bureau of Statistics of China. housing, and the real estate market has developed rapidly (Wang, 2011). In the past ten years, the average selling price of commercial housing has continued to rise from RMB 3,800 per square meter in 2008 to RMB 8736.9 per square meter in 2018 , an increase of 2.3 times. Housing prices in central cities have risen even more rapidly. The increase has even reached more than $20 \%$."Southwestern University of Finance and Economics Family Financial Asset Allocation Risk Report" pointed out that in 2015, real estate accounted for $65.3 \%$ of total assets, and housing was the most important asset in a family's investment portfolio (Yao and Zhang, 2005), In 2015, the average value of Chinese household real estate assets was RMB 586,000, the average value of financial assets [2] was RMB 122,000 , and the average value of risky financial assets was RMB 42,000 (Li Feng, 2016), and the ratio of housing assets to financial assets was 4.8. The ratio of assets reached 14.0. In urban areas, households whose real estate accounts for $65 \%$ of total assets own stocks, while households whose real estate accounts for $75 \%$ choose not to participate in the stock market [3].Therefore, what is the relationship between housing assets and the participation of households' risk financial assets and the degree of participation?

${ }^{2}$ Financial assets mainly include seven types of risky financial assets and deposits, cash, government bonds and government bonds.

3 Data comes from "China Household Finance Survey Report 2016" 
From a theoretical point of view, the impact of housing value on households' risky financial market investment is not certain. On the one hand, the appreciation of housing value will bring huge wealth effects to households, prompting households to invest in high-risk assets (Tobin, 1982). On the other hand, real estate liquidity is poor, and ownership of real estate also allows investors to bear the risk of insufficient liquidity. Therefore, investing in high-priced housing will reduce the proportion of households holding risky assets (Grossman and Laroque, 1990; Chetty and Szeidl, 2007). In China, what kind of situation dominates? The current domestic research has not given a consistent answer to this. Based on this, this article uses household survey data to conduct an empirical study on the impact of housing value appreciation on Chinese households' risky financial asset investment from a micro level, and conducts a robustness test, this is of great practical significance for the government to formulate policies to stabilize housing prices and promote the healthy development of risky financial markets.

The rest of this article is structured as follows. The second part is a literature review. The third part introduces the data source, variable selection and model setting of this article. The fourth part is empirical analysis and main results. The fifth part is the robustness test, the last part is a summary and policy recommendations.

\section{LITERATURE REVIEW}

In recent years, there has been no conclusive conclusion in theoretical and empirical research on the impact of housing prices on risky financial assets. From a theoretical perspective, some scholars believe that the increase in housing value will promote the proportion of household participation and investment in risky financial assets. Goetzmann and Ibbotson (1990) compared the mean and standard deviation of stocks, bonds, treasury bills, commercial and residential real estate through the data of REIT (commercial), CREF (commercial), c\&s (residential), S\&P, LTG bonds and TBILL treasury bills from 1970 to 1986 . It also analyzes the correlation between the annual real estate income and the income of other asset classes, and holds that real estate not only provides comparable returns with bonds and stocks, but also has low correlation with other assets, which is of great significance for diversifying risks for the purpose of asset diversification. Goetzmann (1993) applied the estimated mean, standard deviation and correlation to the meanvariance framework by using the data of risk and return on investment of houses in four cities in the United States from 1971 to 1985 . It was found that due to the low or negative correlation between the income of residential real estate and the income of stocks and bonds in this period, a large part of the effective portfolio was usually used for housing investment to reduce the overall portfolio risk. Yao and Zhang (2005) included non-durable digital consumer goods, house price risk, mortgage requirements and uninsured random labor income in the model of optimal consumption and portfolio selection. The best choice for venture capitalists is to own a house and increase the proportion of stocks in the liquid financial portfolio, so as to take advantage of the diversified income brought by the low correlation between stock returns and housing returns. In addition, Chen Yongwei et al. (2015) examined the impact of housing wealth on household financial market participation and asset allocation decisions. According to a simplified twoperiod model constructed, if the covariance coefficient of the negative or positive correlation between real estate income and financial asset income is small, the housing wealth effect will be dominant compared to the crowding-out effect.

Another part of scholars believe that the increase in housing value will reduce the proportion of households' participation and investment in risky financial assets. Grossman and Laroque (1990) constructed a model of optimal consumption and investment portfolio selection, including houses in durable goods for analysis. Numerical simulations show that liquidity risks make households with higher housing wealth reduce their investment in risky assets. Cocco (2005) constructed an intertemporal investment decision model that included labor income risks and fixed stock market participation costs. Using the US PSID data from 1970 to 1992, simulations found that housing price risk squeezed stock holdings. Chetty and Szeidl (2017) continue to study the impact of housing on investment portfolios based on the housing and portfolio selection model of Cocco (2005). The model integrates the impact of housing illiquidity and price risk, and changes the solution objective to Maximize terminal utility. Using the micro data of housing and asset portfolio in the Income and Plan Participation Survey (SIPP) from 1990 to 2004 in the United States, it is found that the increase of property value (net housing value plus mortgage loan) reduces the share of floating wealth by increasing illiquidity, increasing risk exposure and reducing the present value of lifetime wealth.

From an empirical point of view, domestic and foreign scholars mainly explain the relationship between housing value and risky financial assets from the following aspects. (1) Wealth effect. Cardak and Wilkins (2009) used Australian household, income and labor dynamics (HILDA) survey data to conduct an empirical test and found that the collateral that households can provide through their houses positively affects the ratio of risky financial assets. Chetty and Szeidl (2017) used the micro data of housing and asset portfolio in the US Income and Plan Participation Survey (SIPP) from 1990 to 2004, and found that when the total asset value is fixed, the share of household ownership increases with the increase of the net value of housing. Chen Yongwei et al. (2015) used CHFS 
2011 survey data to find empirically that the increase in real estate wealth will indeed increase the proportion of household risk investments such as stocks. Even after the use of instrumental variables to deal with endogenous issues, the wealth effect is still significant. (2) Asset allocation effect. Yao and Zhang (2005) used PSID data from 1984 to 2001 to conduct an empirical test, it is concluded that the best choice for investors is to own a house and increase the proportion of stocks in the liquid financial investment portfolio, so as to take advantage of the diversified returns brought by the low correlation between stock returns and house returns. Wu Weixing et al. (2014) made use of the data of "Survey of Economic Status and Mentality of Urban Residents in China" by the National Bureau of Statistics in 2009, and adopted logit Regression and other measurement methods to find that with the increase of the number of houses owned by families, the requirement of risk diversification makes it more likely for families with real estate to invest in other financial assets, and the asset allocation effect of families with multiple houses is particularly significant. (3) Crowding out effect. Cocco (2005) conducted an empirical test based on the cross-sectional data of the Income Dynamics Panel Research (PSID), and analyzed the influence of real estate investment on the wealth composition and shareholding level of the portfolio, and found that the housing price risk squeezed out the stock holdings. Kullmann and Siegel (2005) used the PSID data from 1984 to 2001 to make an empirical study, and found that the fluctuation of housing asset price increased the background risk of families, thus reducing the probability of families participating in the stock market, and also reducing the proportion of families holding stocks and other risky financial assets. Shum and Faig (2006) made an empirical study on the determinants of household stock holding by using the data of American consumer finance survey from 1992 to 2001, and found that the participation of stock market and the proportion of stocks in investment portfolio were negatively correlated with investment in own housing.

\section{DATA SOURCE, VARIABLE SELECTION AND MODEL SETTING}

The data used in this article mainly comes from the 2015 "China Household Finance Survey (CHFS)" survey. The survey content includes the demographic characteristics of family members, family assets and liabilities, income status, subjective attitudes, etc., which creates good conditions for us to study the impact of housing value on family risk financial market participation in decision-making and asset allocation. In terms of data processing, this paper eliminates samples with missing values for key variables [4]. In order to avoid extreme observations having a greater impact on the regression coefficients, this article censored $1 \%$ of

4 Variables that have missing values excluded include household income, household net worth, housing value, risk preference attitude, etc. family housing assets and family financial assets. Taking into account the peculiarities of the risky asset investment problem, this article excludes families whose heads of households are younger than 18 years old. After the above-mentioned cleaning of the data, our final sample included a total of 27,655 households.

The explained variables that this paper focuses on are "participation of risk assets (riska) " and "proportion of risk assets to financial assets (risk_ share) ". Following the setting of Yin Zhichao et al. (2014), the risk financial assets defined in this paper mainly include stocks, corporate bonds, financial bonds, funds, financial derivatives, financial wealth management products, foreign exchange and gold. Financial assets include not only risky assets, but also cash, demand deposits, time deposits, government bonds and loans. "Participation in risky financial assets" indicates whether the family holds risky assets in the financial market. If it holds risky financial assets, it takes 1 , but does not take 0 . "The proportion of risky assets" means the proportion of risky assets to financial assets, and the core explanatory variable in this paper is housing assets (asset_house). According to the CHFS questionnaire, the respondent's answer to "How much is this house worth at present" is the housing asset we need.

In order to alleviate the endogenous problem caused by missing variable deviation, we have added enough control variables with reference to relevant literature. According to the literature of Yin Zhichao et al. (2014), family characteristics and the personal characteristics of the head of household will affect the investment behavior of family risk financial assets. We control "family financial assets(asset_f)", "family income ${ }^{5 "}$, "whether the family lives in rural areas", "Unpaid mortgage of the family(house_debt)", "family size","children's dependency ratio(child_rear )", "old age dependency ratio(old_rear)", "social medical insurance(medical_ins)", "head of household age", "financial knowledge", "head of household gender", "years of education of the head of the household(edu_y) [6]", "whether the head of the household is married [7]

5 In order to avoid the endogenous problem of mutual causality between the income from investing in risky financial assets and the investment of risky financial assets, this article refers to the practice of Yin Zhichao and $\mathrm{Wu} \mathrm{Yu}$ et al. (2015), using the total household income minus investment property in the CHFS database Income, and take the logarithm as the family income control variable.

${ }^{6}$ In the questionnaire, the educational years of the head of household who have no schooling, primary school, junior high school, high school, technical secondary school, junior college, undergraduate, master's degree and doctoral degree are converted into $0,6,9,12,13,15,16,19$ and 22 years in turn. 
", "the head of the household risk appetite(risk_pre)", "the head of the household risk aversion(risk_aver)" ${ }^{8}$, "the head of the household healthy". In addition, we also control the provincial virtual variables

7 Take the married family with the head of household as the reference group, with the head of household being married as the value of 1 and others as the value of 0 .

${ }^{8}$ The questions related to family risk attitude in the 2015 CHFS questionnaire are: "If you have an asset, which investment project are you willing to choose: 1 . High-risk, high-return projects; 2 . Projects with slightly higher risks and slightly higher returns; 3. Items with average risk and average return; 4. Projects with slightly lower risks and slightly lower returns; 5 . Unwilling to take any risks ". In this paper, families of 4 and 5 are defined as risk-averse families, families of 3 are defined as risk-neutral families, and families of 1 and 2 are defined as risk-biased families. Taking riskneutral families as the reference group, two virtual variables, risk aversion and risk preference, were set. 
Su Xin., Sch J Econ Bus Manag, May, 2021; 8(5): 136-144

Table-1: Descriptive statistics of main variables

\begin{tabular}{|l|l|l|l|l|l|l|}
\hline variable & mean & sd & min & p50 & max & N \\
\hline riska & 0.160 & 0.370 & 0 & 0 & 1 & 27655 \\
\hline risk_share & 0.0800 & 0.220 & 0 & 0 & 1 & 27655 \\
\hline house & 0.930 & 0.260 & 0 & 1 & 1 & 27655 \\
\hline asset_house & 0.690 & 1.050 & 0 & 0.300 & 6.060 & 27655 \\
\hline house debt & 0.100 & 0.290 & 0 & 0 & 1 & 27655 \\
\hline house_r & 0.710 & 0.260 & 0 & 0.790 & 1.610 & 27655 \\
\hline asset_f & 9.230 & 21.46 & 0.0100 & 1.500 & 143 & 27655 \\
\hline income & 86687 & 210000 & 0 & 50400 & $5.000 \mathrm{e}+06$ & 27655 \\
\hline age & 53.93 & 13.80 & 18 & 53 & 99 & 27655 \\
\hline gender & 0.770 & 0.420 & 0 & 1 & 1 & 27655 \\
\hline marry & 0.880 & 0.320 & 0 & 1 & 1 & 27655 \\
\hline risk_aver & 0.710 & 0.450 & 0 & 1 & 1 & 27655 \\
\hline risk_pre & 0.100 & 0.300 & 0 & 0 & 1 & 27655 \\
\hline health & 0.850 & 0.360 & 0 & 1 & 1 & 27655 \\
\hline edu_y & 9.600 & 4.110 & 0 & 9 & 22 & 27655 \\
\hline rural & 0.310 & 0.460 & 0 & 0 & 1 & 27655 \\
\hline size & 3.630 & 1.650 & 1 & 3 & 20 & 27655 \\
\hline child_rear & 0.0900 & 0.140 & 0 & 0 & 0.710 & 27655 \\
\hline old_rear & 0.180 & 0.310 & 0 & 0 & 1 & 27655 \\
\hline
\end{tabular}

We made descriptive statistical analysis on the main variables, and the results are shown in Table 1 . The average age of the residents interviewed is 54 years old, and $64 \%$ of the families' investment risk attitude is risk aversion. On average, they only have more than 9 years of education, and their overall education level is not high. Among these 27,655 sample families, only $15 \%$ families participate in venture financial assets investment, and $10 \%$ residents own stock investment, so there is a limited participation in venture financial assets. From the perspective of participation, risk financial assets account for only $7 \%$ of all family financial assets, while stock assets account for $4 \%$ of family financial assets, and the proportion of risk financial assets in family financial assets is very low.

\section{(1) Probit model}

Since the probability of household risk financial asset market participation is a two-valued dummy variable, this paper uses the Probit model to analyze the impact of housing value on household risk financial market participation.

$$
\mathrm{Y}=1(\alpha \text { Houseprice }+\mathrm{X} \beta+\mathrm{u}>0)
$$

Among them, $\mathrm{Y}$ is a dummy variable, which is equal to 1 means that the family holds risky financial assets, and no holding is 0 ; Houseprice is the value of the family's housing that this article focuses on; $\mathrm{X}$ is a control variable, mainly family characteristics and demographic variables of the head of the household; $u$ is the disturbance term obeys the normal distribution.

\section{(2) Tobit model}

Since there are a large number of households in the sample that do not participate in the risky financial market, that is, the ratio of risky financial assets to household financial assets is truncated, this article uses the Tobit model to explore the impact of household housing value on the proportion of risky assets in household financial assets.

$$
\begin{gathered}
\mathrm{y}^{*}=\alpha \text { Houseprice }+\mathrm{X} \beta+\mathrm{u} \\
\mathrm{Y}=\max \left(0, \mathrm{y}^{*}\right)
\end{gathered}
$$

Among them, Y represents the observed value of the proportion of risky assets in household financial assets, and all observations less than 0 have been compressed to $0 ; \mathrm{y}^{*}$ is the part of unobservable risk assets that account for more than 0 ; Houseprice is the family housing Value variable; $\mathrm{X}$ is the control variable, which mainly includes household characteristics and demographic variables of the head of the household; $u$ is the disturbance item, which obeys the normal distribution.

\section{EMPIRICAL ANALYSIS OF HOUSING PRICES AND HOUSEHOLD RISK FINANCIAL ASSET INVESTMENT}

(1) The impact of housing prices on household investment in risky financial assets: benchmark return 
Su Xin., Sch J Econ Bus Manag, May, 2021; 8(5): 136-144

Table-2: Housing value and risky financial asset investment

\begin{tabular}{|c|c|c|c|c|c|c|}
\hline & (1) & (2) & (3) & (4) & (5) & (6) \\
\hline VARIABLES & riska & riska & riska & risk_share & risk_share & risk_share \\
\hline \multirow[t]{2}{*}{ asset_house } & $0.412 * * *$ & $0.152 * * *$ & $0.0883 * * *$ & $0.271 * * *$ & $0.0711 * * *$ & $0.0328 * * *$ \\
\hline & $(0.0428)$ & $(0.0234)$ & $(0.0183)$ & $(0.0333)$ & $(0.00969)$ & $(0.00616)$ \\
\hline \multirow[t]{2}{*}{ income } & & $0.138 * * *$ & $0.0793 * * *$ & & $0.0981 * * *$ & $0.0527 * * *$ \\
\hline & & $(0.0134)$ & $(0.00912)$ & & $(0.00907)$ & $(0.00531)$ \\
\hline \multirow[t]{2}{*}{ asset_f } & & $0.0240 * * *$ & $0.0209 * * *$ & & $0.00981 * * *$ & $0.00754 * * *$ \\
\hline & & $(0.000954)$ & $(0.000821)$ & & $(0.000616)$ & $(0.000455)$ \\
\hline \multirow[t]{2}{*}{ size } & & $-0.118 * * *$ & $\overline{0}-0690 * * *$ & & $-0.0728 * * *$ & $-0.0400 * * *$ \\
\hline & & $(0.0111)$ & $(0.0120)$ & & $(0.00751)$ & $(0.00677)$ \\
\hline \multirow[t]{2}{*}{ house_debt } & & $0.324 * * *$ & $0.144 * * *$ & & $0.156 * * *$ & $0.0460 * *$ \\
\hline & & $(0.0356)$ & $(0.0303)$ & & $(0.0231)$ & $(0.0194)$ \\
\hline \multirow[t]{2}{*}{ child_rear } & & $0.191^{*}$ & -0.0345 & & 0.0772 & -0.0348 \\
\hline & & $(0.103)$ & $(0.116)$ & & $(0.0589)$ & $(0.0608)$ \\
\hline \multirow[t]{2}{*}{ old_rear } & & $-0.343 * * *$ & $-0.140 * *$ & & $-0.131 * * *$ & -0.0289 \\
\hline & & $(0.0405)$ & $(0.0643)$ & & $(0.0232)$ & $(0.0344)$ \\
\hline \multirow[t]{2}{*}{ rural } & & $-0.885 * * *$ & $-0.639 * * *$ & & $-0.601 * * *$ & $-0.407 * * *$ \\
\hline & & $(0.0592)$ & $(0.0605)$ & & $(0.0367)$ & $(0.0348)$ \\
\hline \multirow[t]{2}{*}{ age } & & & $0.0309 * * *$ & & & $0.0175 * * *$ \\
\hline & & & $(0.00662)$ & & & $(0.00366)$ \\
\hline \multirow[t]{2}{*}{$\operatorname{age}^{2}$} & & & $\begin{array}{l} \\
0.0228 * * *\end{array}$ & & & $-0.0120 * * *$ \\
\hline & & & $(0.00612)$ & & & $(0.00334)$ \\
\hline \multirow[t]{2}{*}{ gender } & & & $-0.170 * * *$ & & & $-0.111 * * *$ \\
\hline & & & $(0.0314)$ & & & $(0.0198)$ \\
\hline \multirow[t]{2}{*}{ marry } & & & $0.174 * * *$ & & & $0.105 * * *$ \\
\hline & & & $(0.0429)$ & & & $(0.0257)$ \\
\hline \multirow[t]{2}{*}{ risk_aver } & & & $-0.328 * * *$ & & & $-0.185 * * *$ \\
\hline & & & $(0.0296)$ & & & $(0.0188)$ \\
\hline \multirow[t]{2}{*}{ risk_pre } & & & $0.317 * * *$ & & & $0.154 * * *$ \\
\hline & & & $(0.0426)$ & & & $(0.0197)$ \\
\hline \multirow[t]{2}{*}{ health } & & & 0.0305 & & & $0.0377 * *$ \\
\hline & & & $(0.0361)$ & & & $(0.0186)$ \\
\hline \multirow[t]{2}{*}{ edu_y } & & & $0.0863 * * *$ & & & $0.0500 * * *$ \\
\hline & & & $(0.00484)$ & & & $(0.00355)$ \\
\hline \multirow[t]{2}{*}{ medical_ins } & & & $0.142 * * *$ & & & $0.0766 * *$ \\
\hline & & & $(0.0512)$ & & & $(0.0299)$ \\
\hline \multirow[t]{2}{*}{ finance_know } & & & $0.233 * * *$ & & & $0.121 * * *$ \\
\hline & & & $(0.0153)$ & & & (0.00979) \\
\hline \multirow[t]{2}{*}{ Constant } & $-1.527 * * *$ & $-2.456 * * *$ & $-4.140 * * *$ & $-1.083 * * *$ & $-1.563 * * *$ & $-2.386 * * *$ \\
\hline & $(0.130)$ & $(0.145)$ & $(0.224)$ & $(0.122)$ & $(0.0188)$ & $(0.141)$ \\
\hline Pseudo $\mathrm{R}^{2}$ & 0.15 & 0.337 & 0.403 & 0.13 & 0.283 & 0.345 \\
\hline Observations & 27,655 & 27,655 & 27,655 & 27,655 & 27,655 & 27,655 \\
\hline
\end{tabular}

Note: The standard deviation of the cluster at the city level are in parentheses; *,**, and *** indicate the significance levels of $10 \%, 5 \%$, and $1 \%$, respectively. The following table is the same.

Analyzing Table-2, we first focus on the impact of the core explanatory variable housing value on household risk asset participation. From the perspective of whether households hold risk financial assets and whether they hold stocks in columns (1) and (2), housing Asset appreciation has a significant negative impact on household participation in risky financial assets. The explained variables in column (3) and column (4) are respectively the proportion of risky financial assets to household financial assets and the proportion of stocks to household financial assets. It can be seen that the negative impact of housing value on the proportion of risky financial assets is still significant at the level of 5\%. Therefore, we can learn from empirical evidence that there is no wealth effect or asset allocation effect in housing price increase, but the investment in risky financial assets is significantly reduced through crowding out effect, which is consistent with the conclusion of Kullmann and Siegel (2005) 
Su Xin., Sch J Econ Bus Manag, May, 2021; 8(5): 136-144

Secondly, most of the control variables also significantly affect the family's participation in venture financial assets, among which the family resource endowment variables include family income and family net assets, which are significantly positively related to the family holding venture financial assets or stocks; Family size and rural areas have significantly reduced their participation in risky financial assets. There is a nonlinear relationship between age and holding risky financial assets. Risk-averse household heads are even less willing to participate in the risky financial market, and families with higher education level tend to participate in the investment of risky financial assets. It is also found that the dependency ratio of children, whether health and family hold risky financial assets and the proportion of risky financial assets have no significant influence.

\section{ROBUSTNESS ANALYSIS \\ (1) Instrumental Variable Method}

Housing assets are closely related to unobservable family characteristics, such as personality characteristics and life experience, and these factors also affect family asset allocation decisions. If these factors are ignored, they may cause estimation bias. In order to solve the potential endogeneity problem, we use a variety of methods to try to reduce the estimation bias caused by the endogeneity problem as much as possible. First, control more variables that may have an impact on stock investment. In this regression, not only sufficient family characteristic variables and personal characteristic variables are added, but also province dummy variables are controlled. The instrumental variable method requires that the selected instrumental variable is highly correlated with the explanatory variable it replaces and is not correlated with the error term that is, looking for variables that are related to family housing assets but independent of family asset allocation behavior as instrumental variables. According to Chen Yongwei and others (2015), this paper uses "housing wealth appreciation" as an Instrumental variable of housing wealth. In recent years, China's real estate has increased rapidly, and a large part of the value of real estate is brought about by the appreciation after buying a house. In this sense, there is a strong correlation between "housing wealth appreciation" and housing wealth. At the same time, the rapid increase in housing prices in China is more of a kind of "uncertainty." Most households did not anticipate the subsequent appreciation of their houses at the initial stage of their purchases. Therefore, the correlation between "housing wealth appreciation" and household characteristics is weak, and has a better exogenous nature. Based on the above reasons, it is reasonable to think that "housing wealth appreciation" is a good instrumental variable for "housing wealth". Table-3 reports the results of the IVProbit model and the IVTobit model that use housing wealth appreciation as an instrumental variable. Panel a reports the results of Wald's test of the endogenity of housing wealth appreciation, and both significantly reject the null hypothesis that there is no endogeneity. We also reported the first-stage results of the two-step method in Panel B in Table-3. The instrumental variable coefficient is significant at $1 \%$, and the first-stage $\mathrm{F}$ statistic is also greater than the empirical value of 10 , indicating that the instrumental variable is not a weak instrumental variable. (Stock and Yogo, 2005). After using instrumental variables, the positive effects of housing assets on risky financial asset investment are all significant at the $1 \%$ level.

Table-3: Housing wealth appreciation (instrumental variable)

\begin{tabular}{|c|c|c|c|c|}
\hline & $\begin{array}{l}1) \\
\text { riska }\end{array}$ & $\begin{array}{c}(2) \\
\text { risk_share }\end{array}$ & $\begin{array}{l}(3) \\
\text { stock } \\
\end{array}$ & $\begin{array}{c}\text { (4) } \\
\text { stock_share }\end{array}$ \\
\hline & Ivprobit & Ivprobit & Ivtobit & Ivtobit \\
\hline & & Panel A & & \\
\hline \multirow[t]{2}{*}{ asset_house } & $0.380 * * *$ & $0.0922 * * *$ & $0.255^{* * *}$ & $0.0374 * * *$ \\
\hline & $(0.0101)$ & $(0.0131)$ & $(0.00726)$ & $(0.00654)$ \\
\hline control variables & $\mathrm{N}$ & $\mathrm{Y}$ & $\mathrm{N}$ & $\mathrm{Y}$ \\
\hline Observations & 27,655 & 27,655 & 27,655 & 27,655 \\
\hline Wald test & 36.52 & 5.35 & 39.38 & 3.67 \\
\hline \multirow[t]{2}{*}{ ( $\mathrm{p}$ value $)$} & $(0.0000)$ & $0.0207)$ & $(0.0000)$ & $(0.0555)$ \\
\hline & & Panel B & & \\
\hline \multirow[t]{2}{*}{ Housing wealth appreciation } & $1.056 * * *$ & $1.008 * * *$ & $1.056 * * *$ & $1.008 * * *$ \\
\hline & $(0.0150)$ & $(0.00962)$ & $(0.0150)$ & $(0.00962)$ \\
\hline F statistic value in the first stage & 9211.66 & 6996.06 & 9211.66 & 6996.06 \\
\hline
\end{tabular}

\section{(2) Other robustness analysis}

The explanatory variable housing value in this article is derived from the respondent's own valuation, and the respondent's own unobservable variables also affect the household's risky financial asset allocation decision. If these are ignored, it may cause estimation bias. For example, people who have failed in stock investment will be more inclined to think that the housing appreciation is high and allocate less risky financial assets. According to Chen Yongwei's method (2015), Probit and Tobit regression were carried out with the samples of housing purchased before 1998, 
Su Xin., Sch J Econ Bus Manag, May, 2021; 8(5): 136-144

because before 1998, the national housing policy emphasized welfare, and the price of the real estate market changed smoothly, and residents rarely bought housing for investment purposes. Therefore, most of the value of the houses purchased before 1998 comes from exogenous increment. Using this part of samples for analysis can better avoid certain endogenous problems.

Table-4: Impact of Housing Assets and Family Risk Financial Assets Investment: Sub-sample

\begin{tabular}{|l|l|l|l|l|}
\hline & $(\mathbf{1})$ & $\mathbf{( 2 )}$ & $\mathbf{( 3 )}$ & $\mathbf{( 4 )}$ \\
\hline VARIABLES & riska & risk_share & Stock & stock_share \\
\hline asset_house & $0.0914 * * *$ & $0.0333 * * *$ & $0.0938^{* * *}$ & $0.0368^{* * *}$ \\
\hline & $(0.0199)$ & $(0.00705)$ & $(0.0189)$ & $(0.00651)$ \\
\hline $\begin{array}{l}\text { control } \\
\text { variables }\end{array}$ & $\mathrm{Y}$ & $\mathrm{Y}$ & $\mathrm{Y}$ & $\mathrm{Y}$ \\
\hline Constant & $-4.087 * * *$ & $-2.362 * * *$ & $-4.073 * * *$ & $-2.357 * * *$ \\
\hline & $(0.250)$ & $(0.151)$ & $(0.249)$ & $(0.152)$ \\
\hline Observations & 26,034 & 26,034 & 26,034 & 26,034 \\
\hline
\end{tabular}

From Table-4, it can be seen that the regression results after using the samples purchased before 1998 to deal with endogeneity are basically consistent with the benchmark regression results, and the increase in housing value will significantly reduce the participation of risky assets and the proportion of investment.

\section{(3) Sample of towns}

Considering that China's housing purchase behavior is mainly reflected in urban areas, while rural households are mostly self-built houses, and the economic decision-making behaviors of rural and urban households in China are quite different, this paper only retains urban samples for the following regression.

Table-5: Sample of cities and towns

\begin{tabular}{|l|l|l|l|l|}
\hline & $\mathbf{( 1 )}$ & $\mathbf{( 2 )}$ & $\mathbf{( 3 )}$ & $\mathbf{( 4 )}$ \\
\hline VARIABLES & riska & risk_share & riska & risk_share \\
\hline asset_house & $0.0871 * * *$ & $0.0321 * * *$ & $0.0922 * * *$ & $0.0373 * * *$ \\
\hline & $(0.0188)$ & $(0.00621)$ & $(0.0189)$ & $(0.00609)$ \\
\hline $\begin{array}{l}\text { control } \\
\text { variables }\end{array}$ & $\mathrm{Y}$ & $\mathrm{Y}$ & $\mathrm{Y}$ & $\mathrm{Y}$ \\
\hline Constant & $-4.213 * * *$ & $-2.369 * * *$ & $-4.202 * * *$ & $-2.364 * * *$ \\
\hline & $(0.222)$ & $(0.139)$ & $(0.221)$ & $(0.140)$ \\
\hline Observations & 19,196 & 19,196 & 19,196 & 19,196 \\
\hline
\end{tabular}

As shown in the above table, even after excluding rural sample households, housing assets will still significantly affect the investment of household risk financial assets. This further validates the results of our benchmark regression. In addition, after we use the increase in housing assets as an explanatory variable, the results are still robust.

\section{CONCLUSIONS AND POLICY RECOMMENDATIONS}

This article uses the empirical survey of the China Household Finance Survey (CHFS) in 2015 to find that housing assets will not only significantly increase household participation in risky financial assets, but also increase household investment in risky financial assets. House price wealth has a significant wealth effect, which increases investment in risky financial assets. After the endogenity is processed in time through the instrumental variable method, the wealth effect of housing is still significant. Therefore, while encouraging the healthy and prosperous development of the housing market, we must also pay attention to actively improve China's capital market and ensure the safety of investors' investment. Second, speed up the establishment of a housing system featuring multi-subject supply, multi-channel guarantee, and simultaneous rental and purchase. Third, each locality should take into account the actual conditions of its own real estate market, implement policies in accordance with the city, improve the housing market system and housing security system, further stabilize land prices, stabilize housing prices, and stabilize expectations.

\section{REFERENCES}

1. Yang, C. (2004). Develop the Capital Market and Broaden the Investment Channels of Residents [J]. Financial Theory and Practice, 07; 36-38.

2. Wang, S.Y. (2011). State Misallocation and Housing Prices: Theory and Evidence from China [J]. American Economic Review, 101; 2081-2107.

3. Yao, R, Zhang, H.H. (2005). Optimal Consumption and Portfolio Choices with Risky Housing and Borrowing Constraints [J]. Review of Financial Studies, 18(1): 197-239.

4. Li, F., Luo, J., Lu, X., Deng, B., Gan, L.I. (2016). The Status, Change Trend and Influencing Factors of Chinese Household Assets [J]. Management 
Su Xin., Sch J Econ Bus Manag, May, 2021; 8(5): 136-144

World,02; 45-56.

5. Tobin, J. (1982). Asset Accumulation and Economic Activity: Reflections on Contemporary Maeroeconomic Theory, University of Chicago Pres.

6. Grossman, S.J., Guy, L. (1987). Asset Pricing and Optimal Portfolio Choice in the Presence of Illiquid Durable Consumption Goods [J].

7. Chetty, R., Szeidl, A. (2017). The Effect of Housing on Portfolio Choice [J]. The Journal of Finance, 72.3; 1171-1212.

8. Goetzmann, W.N., Ibbotson, R.G. (1990). The Performance of Real Estate as an Asset Class [J]. Journal of Applied Corporate Finance, 3(1), 65-76.

9. Goetzmann, W.N. (1993). The Single Family Home in the Investment Portfolio [J]. The Journal of Real Estate Finance and Economics, 6(3): 201222.

10. Chen, Y, Shi, Y., Quan, W. H. (2015). Wealth, Financial Market Participation and Household Asset Portfolio Selection: Evidence from Chinese Cities [J]. Financial Research, 04; 1-18.

11. Cocco, J. F. (2005). Portfolio choice in the presence of housing. The Review of Financial Studies, 18(2), 535-567.

12. Cardak, B. A., \& Wilkins, R. (2009). The determinants of household risky asset holdings:
Australian evidence on background risk and other factors. Journal of banking \& Finance, 33(5), 850860.

13. Wu, W. X., Shen, T., \& Jiang, T. (2014). Do Real Estate Assets Crowd out Household's Risky Assets Allocation? An Empirical Analysis Based on Micro-survey Data. Scientific Decision Making, 11, 52-69.

14. Kullmann, C., \& Siegel, S. (2005, November). Real estate and its role in household portfolio choice. In EFA 2003 annual conference paper (No. 918).

15. Shum, P., \& Faig, M. (2006). What explains household stock holdings?. Journal of Banking \& Finance, 30(9), 2579-2597.

16. Zhichao, Y., Quanyun, S., \& Yu, W. (2014). Financial literacy, trading experience and household portfolio choice. Economic Research Journal, 04.

17. Zhichao, Y., Yu, W., \& Li, G. (2015). Financial availability, financial Market participation and household portfolio choice [J]. Economic Research Journal, 3, 89-101.

18. Stock, J. H., \& Yogo, M. (2005). Testing for weak instruments in linear IV regression. Identification and inference for econometric models: Essays in honor of Thomas Rothenberg, 80(4.2), 1 . 